\title{
The S1P receptor modulator FTY720 prevents the development of experimental colitis in mice
}

\author{
YASUYUKI DEGUCHI, AKIRA ANDOH, YUKI YAGI, SHIGEKI BAMBA, \\ OSAMU INATOMI, TOMOYUKI TSUJIKAWA and YOSHIHIDE FUJIYAMA
}

Department of Internal Medicine, Shiga University of Medical Science, Seta Tukinowa, Otsu 520-2192, Japan

Received March 27, 2006; Accepted June 6, 2006

\begin{abstract}
To evaluate the therapeutic effects of the new synthetic sphingosine-1-phosphate $(\mathrm{S} 1 \mathrm{P})$ receptor modulator, FTY720, we investigated how FTY720 affects the development of dextran sulfate sodium (DSS)-induced colitis and $\mathrm{CD} 4{ }^{+} \mathrm{CD} 62 \mathrm{~L}^{+} \mathrm{T}$ cell transfer colitis. BALB/c mice were fed a chow containing $3.5 \%$ (wt/wt) DSS to induce colitis. The $\mathrm{CD} 4{ }^{+} \mathrm{CD} 62 \mathrm{~L}^{+} \mathrm{T}$ cell transfer colitis was induced by an intraperitoneal injection of $\mathrm{CD}^{+} \mathrm{CD} 62 \mathrm{~L}^{+}$spleen $\mathrm{T}$ cells into recipient CB17 SCID mice. The FTY720 was administered by lavage at a dose of $0.3 \mathrm{mg} / \mathrm{kg} /$ day. FTY720 was effective in preventing the body weight loss in the DSS-colitis model and the $\mathrm{CD}^{+}{ }^{+} \mathrm{CD} 62 \mathrm{~L}^{+} \mathrm{T}$ cell transfer model. The disease activity index, histological colitis score, and MPO activity were all significantly lower in FTY720-treated mice than in the nontreated mice. Microscopically, mucosal edema, cellular infiltration and epithelial disruption were much more moderate in the FTY720-treated mice than in the non-treated mice. In both colitis models, FTY720 prevented the infiltration of $\mathrm{CD}^{+} \mathrm{T}$ cells into the inflamed colonic lamina propria. In conclusion, the development of DSS-colitis and CD4 ${ }^{+} \mathrm{CD} 62 \mathrm{~L}^{+} \mathrm{T}$ cell transfer colitis were significantly attenuated by FTY720. Since FTY720 is an immunosuppressive product that does not modulate $\mathrm{T}$ cell functions, it could be useful in the treatment of IBD patients.
\end{abstract}

\section{Introduction}

Inflammatory bowel disease (IBD), such as ulcerative colitis (UC) and Crohn's disease (CD), are associated with chronic relapsing inflammation of the intestinal tract of unknown etiology (1-4). Histologically, the mucosal accumulation of leukocytes is a characteristic feature of IBD, and the activation of $\mathrm{T}$ cells and monocytes/macrophages is regarded as a crucial

Correspondence to: Dr Akira Andoh, Department of Internal Medicine, Shiga University of Medical Science, Seta Tukinowa, Otsu 520-2192, Japan

E-mail: andoh@belle.shiga-med.ac.jp

Key words: immunosuppressant, DSS-colitis, $\mathrm{CD} 4{ }^{+} \mathrm{CD} 62 \mathrm{~L}^{+} \mathrm{T}$ cell transfer models factor in its pathogenesis. The treatment of IBD depends on drugs such as 5-aminosalicyclic acid, corticosteroids, azathioprine, mercaptopurines and cyclosporine (1). However, the use of these drugs is sometimes limited by drug-induced toxicity. Thus, there is an increasing need for alternative agents that may be equally or more effective but toxicity-free.

The new synthetic sphingosine-1-phosphate $(\mathrm{S} 1 \mathrm{P})$ receptor modulator FTY720 \{2-amino-2-[2-(4-octyl-phenyl) ethyl]1,3-propanediol hydrochloride $\}$ is a derivative of ISP-1 (myriocin) isolated from the fungus Isaria Sinclairi (5-11). FTY720 discloses S1P receptor signalling to be essential for lymphocytes to egress from lymph nodes and thymus (12), and the oral administration of FTY720 induces a rapid reduction of peripheral blood lymphocytes. FTY720 shifts the distribution of lymphocytes from the peripheral blood and spleen to secondary lymphoid tissues such as the Peyer's patches, peripheral lymph nodes and mesenteric lymph nodes (5-10). This cell redistribution is responsible for the immunosuppressive activity of FTY720, and the functions of the granulocytes, monocytes, and $\mathrm{T}$ and $\mathrm{B}$ cells remain unimpaired. Thus, the immunosuppressive mechanism of FTY720 differs markedly from other drugs currently used as immunosuppressive agents.

The therapeutic effects of FTY720 for spontaneous colitis developed in interleukin-10 gene-deficient (IL-10-/-) mice have been reported (13). To further evaluate the therapeutic effects of FTY720 on other models of experimental colitis, we used the dextran sulfate sodium (DSS)induced colitis and $\mathrm{CD} 4{ }^{+} \mathrm{CD} 62 \mathrm{~L}^{+} \mathrm{T}$ cell transfer models of colitis $(14,15)$. Since FTY720 does not cause any impairment in $\mathrm{T}$ cell functions, it is worthwhile to investigate the effects of FTY720 on experimental colitis as a novel candidate for a new therapeutic approach for IBD.

\section{Materials and methods}

Induction of experimental colitis. For the induction of DSScolitis, six- to eight-week old male BALB/c mice were purchased from Charles River Japan (Kanagawa, Japan). They were acclimatized for one week before the experiment, and were housed individually in a room maintained at $22^{\circ} \mathrm{C}$ under a 12-h day/night cycle throughout the experiments. The mice were fed $3.5 \%$ (wt/wt) DSS (molecular weight 5000; Wako Pure Chemical Industries, Ltd., Osaka, Japan) mixed with normal chow (MF; Oriental Yeast Co., Ltd., Tokyo, Japan) and water ad libitum. The study protocol was approved 
by the Animal Care and Use Committee of the Shiga University of Medical Science (Otsu, Japan).

For the induction of the $\mathrm{CD} 4{ }^{+} \mathrm{CD} 62 \mathrm{~L}^{+} \mathrm{T}$ cells transfer model of colitis, $\mathrm{CD}^{+} \mathrm{T}$ cells were purified from the spleen mononuclear cells of healthy $\mathrm{BALB} / \mathrm{c}$ mice by the negative depletion of other cell types using anti-CD8, anti-MHC-II, anti-B220 and anti-11b antibodies (Pharmingen, Hamburg, Germany) $(15,16)$, and anti-rat IgG immunomagnetic microbeads (Miltenyi Biotech, Bergisch Gladbach, Germany). The $\mathrm{CD} 4{ }^{+} \mathrm{T}$ cells were further separated into $\mathrm{CD} 62 \mathrm{~L}^{+}$and CD62L- $\mathrm{T}$ cells. The $\mathrm{CD} 4{ }^{+} \mathrm{CD} 62 \mathrm{~L}^{+} \mathrm{T}$ cells $\left(0.25 \times 10^{6}\right.$ cells $)$ were resuspended in $200 \mu 1$ of sterile phosphate-buffered saline (PBS) and were injected intraperitoneally in recipient CB17 SCID mice (Charles River Japan) $(15,16)$.

Each colitis model was divided into two subgroups, and one subgroup was treated with FTY720 (Novartis Pharma AG, Basel, Switzerland). The FTY720 was administered by lavage at a dose of $0.3 \mathrm{mg} / \mathrm{kg} /$ day for 14 days in the DSS colitis model and for 49 days in the $\mathrm{CD} 4{ }^{+} \mathrm{CD} 62 \mathrm{~L}^{+} \mathrm{T}$ cell transfer model, respectively. The control mice received distilled water alone.

Assessment of inflammation in DSS-induced colitis. A daily clinical assessment of the colitis was performed, including a measurement of food intake and body weight, an evaluation of stool consistency, and the presence of blood in the stools by a guaiac paper test. The stool consistency was assessed using the following four point-scale: 0 , normal; 1 , soft; 2 , very soft but formed; and 3, liquid. The intensity of the guaiac paper test was scored by the following scale: 0 , negative; 1 , faintly blue; 2 , moderately blue; 3 , dark blue; and 4 , blood visible. A validated clinical disease activity index ranging from 0 to 4 was calculated using the following parameters: stool consistency, presence of fecal blood, and changes in body weight (17). The mice were sacrificed on the last day, and the length and weight of the colons were measured.

Histology. A histological examination was performed on three samples of the distal colon from each animal. The samples were fixed in $10 \%$ buffered formalin, dehydrated in ethanol, and then embedded in paraffin. Four micron-thick sections were then prepared and stained with hematoxylin and eosin. All histologic evaluation was performed in a blinded fashion using a validated scoring system.

For immunohistochemical staining, freshly isolated colonic tissue from the distal portion of the colon was frozen in dry ice using an OCT compound (Sakura Finetek, Tokyo, Japan). Acetone-fixed frozen sections (6- $\mu \mathrm{m}$ thick) were blocked with Dako blocking reagent (\#X0909, Dako Japan, Kyoto, Japan) followed by incubation with the primary antibodies [antimouse CD4 (BD Pharmingen, San Diego, CA)] diluted 1:100 in phosphate-buffered saline (PBS) containing 5\% skim milk overnight at $4^{\circ} \mathrm{C}$ in a humidified chamber. After incubation with the primary antibody, the sections were reacted with $0.1 \%$ $\mathrm{H}_{2} \mathrm{O}_{2}$ in $0.1 \mathrm{M}$ PBS, and treated with biotin-conjugated second antibodies (diluted 1:50 in PBS containing 1\% skim milk; Vector, Burlingame, CA) for $60 \mathrm{~min}$ at room temperature.

Tissue myeloperoxidase activity. The samples were washed with cold PBS, blotted dry, and were immediately thawed for
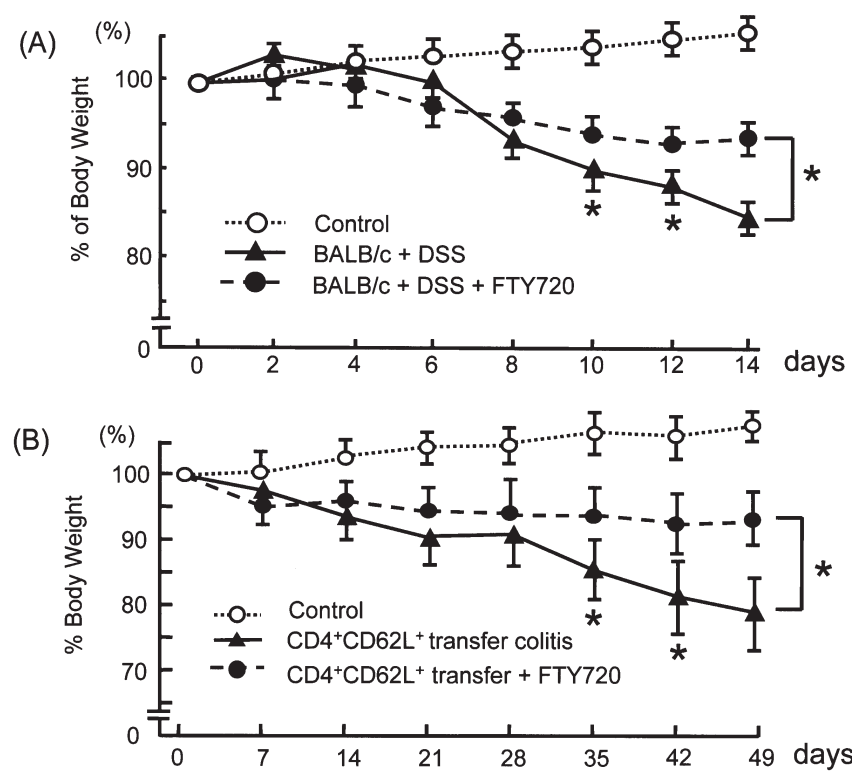

Figure 1. Changes in the body weight of DSS-colitis mice (A) and $\mathrm{CD} 4{ }^{+} \mathrm{CD} 62 \mathrm{~L}^{+} \mathrm{T}$ cell transfer-colitis mice (B). The mice in the DSS-colitis model were fed DSS over 14 days, and the mice in the CD4 ${ }^{+} \mathrm{CD} 62 \mathrm{~L}^{+} \mathrm{T}$ cell transfer-colitis model were followed for 49 days. The weight of each individual mouse was ascored daily. The data represent means \pm SD ( $n=5$ mice/ group). ${ }^{*} \mathrm{P}<0.05$.

the myeloperoxidase activity determination using the Odianisidine method previously described. The activity was expressed as the amount of enzyme necessary to generate a change in absorbance of 1.0 per minute per gram wet weight of tissue.

Statistical analysis. Statistical analyses were performed using a one-way ANOVA with Scheffe's post hoc test or the KruskalWallis test when appropriate. A two-way ANOVA for repeated measures was used to test for group and time effects on clinical data (e.g., the disease activity index). A P-value $<0.05$ was considered to be statistically significant.

\section{Results}

As shown in Fig. 1A, on days 10,12 and 14 after the initiation of DSS-induced colitis, the body weight loss was much more severe in the DSS-treated mice than in the DSS plus FTY720treated mice. Similarly, in the $\mathrm{CD} 4{ }^{+} \mathrm{CD} 62 \mathrm{~L}^{+} \mathrm{T}$ cell transfer model, FTY720 exerted significant preventive effects against the body weight loss on days 35,42 and 49 after the induction of colitis (Fig. 1B). The disease activity index was significantly lower in the DSS plus FTY720-treated mice than in the DSStreated mice ( $\mathrm{P}<0.05$, Fig. $2 \mathrm{~A})$, and was significantly lower in the FTY720-treated $\mathrm{CD} 4{ }^{+} \mathrm{CD} 62 \mathrm{~L}^{+} \mathrm{T}$ cell transfer models than in the non-treated colitis models ( ${ }^{*} \mathrm{P}<0.05$, Fig. $\left.2 \mathrm{~B}\right)$.

On day 14, the colon length shortening was much more severe in the DSS-treated mice as compared to the DSS plus FTY720-treated mice ( ${ }^{*} \mathrm{P}<0.05$, Fig. 3a). The colon weight/ length ratio, a maker of tissue edema, was significantly higher in the DSS-treated mice than in the DSS plus FTY720-treated mice ( ${ }^{*} \mathrm{P}<0.05$, Fig. 3b). Similarly, in the $\mathrm{CD} 4{ }^{+} \mathrm{CD} 62 \mathrm{~L}^{+} \mathrm{T}$ cell transfer model, FTY720 significantly ameliorated both the 

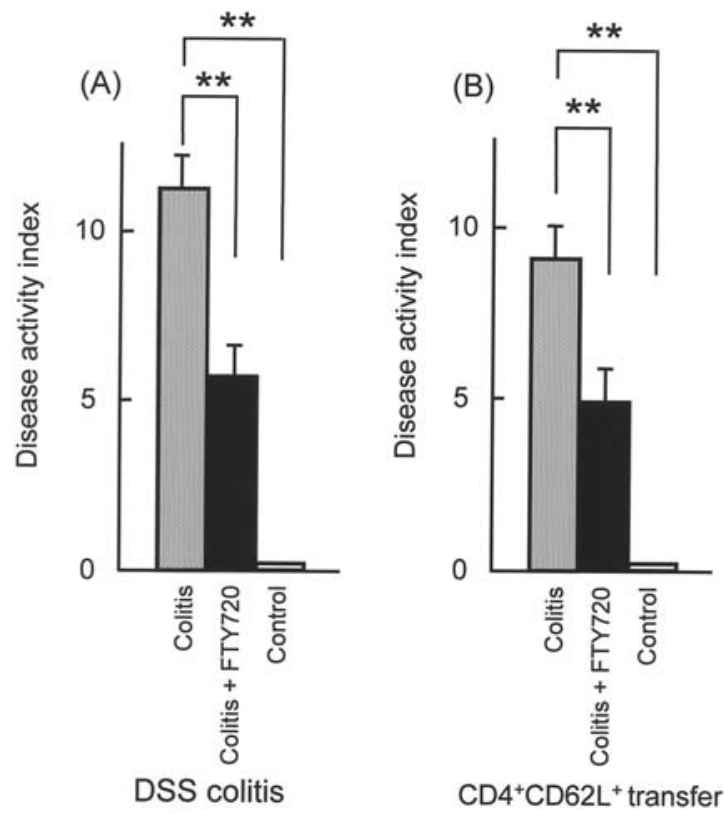

Figure 2. Disease activity index on day 14 in the DSS-colitis model (A) and on day 49 in the $\mathrm{CD}^{+}{ }^{+} \mathrm{CD} 62 \mathrm{~L}^{+} \mathrm{T}$ cell transfer-colitis model. The data represent means $\pm \mathrm{SD}\left(\mathrm{n}=5\right.$ mice/group). ${ }^{* *} \mathrm{P}<0.01$.

colon length shortening and the increase in the colon weight/ length ratio $\left({ }^{*} \mathrm{P}<0.05\right.$, Fig. $3 \mathrm{c}$ and $\left.\mathrm{d}\right)$.

DSS-colitis is characterized by histological findings such as edema, the infiltration of inflammatory cells into both the mucosa and submucosa, the destruction of epithelial cells and mucosal thickening. As shown in Fig. 4A, the histological

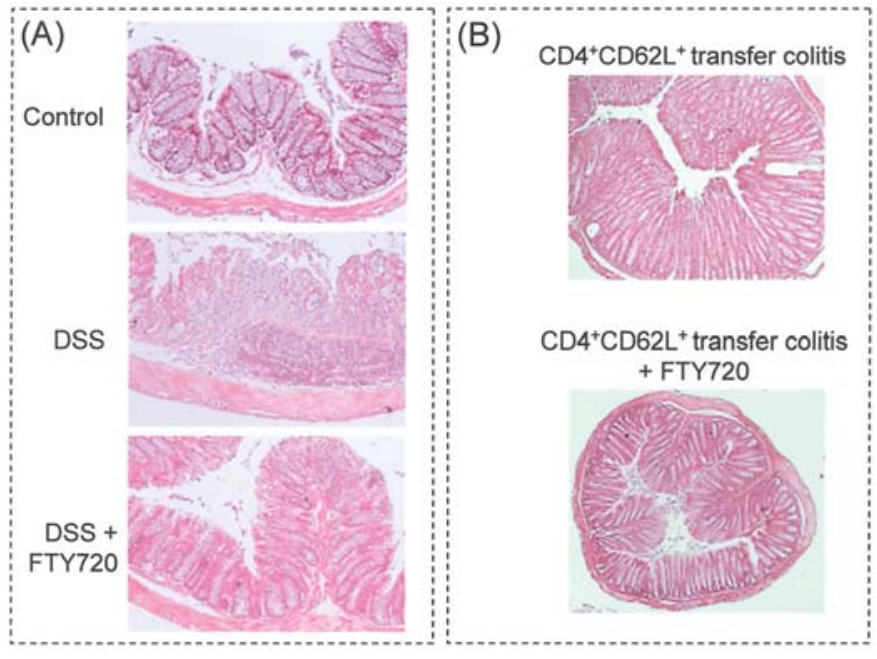

Figure 4. Histologic findings in the DSS-colitis model on day 14 (A) and in the $\mathrm{CD}^{+}{ }^{+} \mathrm{CD} 62 \mathrm{~L}^{+} \mathrm{T}$ cell transfer-colitis model on day 49 (B). The colons were excised, and stained with hematoxylin and eosin. Magnification x20.

analysis indicated that these changes were more severe in the DSS-treated mice as compared to the DSS plus FTY720-treated mice. Similarly, CD4 ${ }^{+} \mathrm{CD} 62 \mathrm{~L}^{+} \mathrm{T}$ cell transfer colitis is also characterized by marked elongation of the intestinal crypts, mucosal thickening, edema, severe infiltration of inflammatory cells, and epithelial destruction. These histological changes were much milder in the FTY720-treated mice than in the nontreated mice (Fig. 4B). The histological score was significantly lower in the FTY720-treated colitis models than in the non-treated colitis models $\left({ }^{*} \mathrm{P}<0.05\right.$, Fig. $\left.5 \mathrm{~A}\right)$.
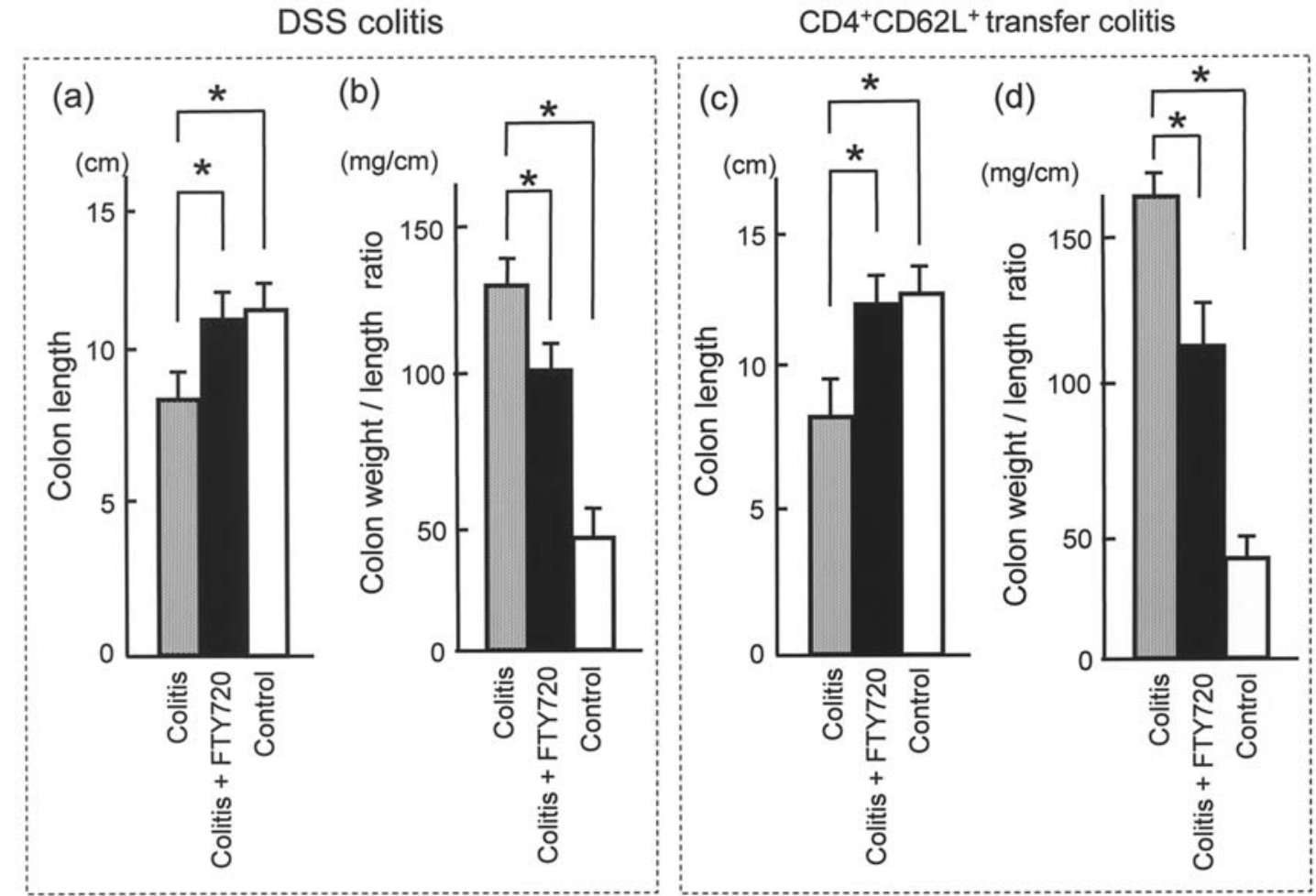

Figure 3. Colon length and colon weight/length ratio on day 14 in the DSS-colitis model and on day 49 in the $\mathrm{CD}^{+} \mathrm{CD} 62 \mathrm{~L}^{+} \mathrm{T}$ cell transfer-colitis model. The data represent means $\pm \mathrm{SD}\left(\mathrm{n}=7\right.$ mice/group). ${ }^{*} \mathrm{P}<0.05$. 


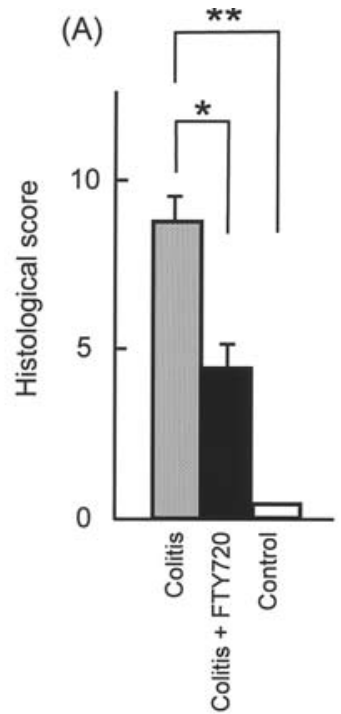

DSS colitis

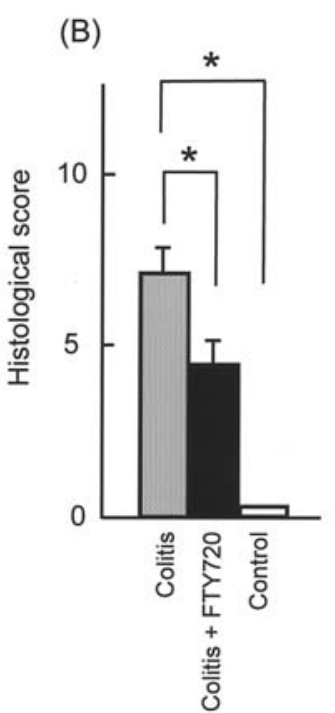

$\mathrm{CD} 4^{+} \mathrm{CD} 62 \mathrm{~L}^{+}$transfer

Figure 5. Histological score in the DSS-colitis model on day 14 (A) and in the $\mathrm{CD}^{+}{ }^{+} \mathrm{CD} 62 \mathrm{~L}^{+} \mathrm{T}$ cell transfer-colitis model on day $49(\mathrm{~B})$. The data represent means $\pm \mathrm{SD}$ ( $\mathrm{n}=5$ mice/group). ${ }^{*} \mathrm{P}<0.05,{ }^{* *} \mathrm{P}<0.01$.

As shown in Fig. 6A, the tissue myeloperoxidase activity, a marker of granulocyte infiltration, as well as the number of infiltrated $\mathrm{CD}^{+} \mathrm{T}$ cells were all significantly lower in the DSS plus FTY720-treated mice than in the DSS-treated mice $\left({ }^{*} \mathrm{P}<0.05\right.$, Fig. 6A). Similarly, these markers were significantly lower in the FTY720-treated $\mathrm{CD} 4{ }^{+} \mathrm{CD} 62 \mathrm{~L}^{+} \mathrm{T}$ cell transfer models than in the non-treated colitis models $\left({ }^{*} \mathrm{P}<0.05\right.$, Fig. 6B).

\section{Discussion}

FTY720 has emerged as a potent S1P receptor immunomodulator with usefulness in the control of organ transplant rejection and for the treatment of autoimmune diseases. In animal models, FTY720 is efficacious in prolonging graft survival, as well as in models of multiple sclerosis, acute lung injury, autoimmune diabetes, atherosclerosis and renal ischemia-reperfusion injury (18). Promising results have also been obtained from human trials on FTY720 for indications in renal transplantation and multiple sclerosis $(19,20)$. In contrast to conventional immunosuppressants such as cyclosporine A or FK506, FTY720 selectively and reversibly sequesters lymphocytes but not monocytes or granulocytes from the blood and spleen into secondary lymphoid organs, thereby preventing their migration toward sites of inflammation and allograft rejection (5-11). Moreover, FTY720 does not impair $\mathrm{T}$ cell activation, expansion, and memory functions, and does not induce $\mathrm{T}$ cell apoptosis (11). Recent studies also demonstrated that FTY720 enhances functions of the $\mathrm{CD} 4{ }^{+} \mathrm{CD} 25^{+}$-regulatory $\mathrm{T}$ cells (11), and that FTY720 alters IL-12 secreting dendritic cells to IL-10 producing cells (8). These mechanisms represent the overall immunosuppressive actions of FTY720.

Mizushima et al demonstrated that FTY720 prevented the development of spontaneous colitis in IL-10 $10^{-/}$mice (13). Colitis in IL-10-1- mice is characterized by the infiltration of activated $\mathrm{CD}^{+} \mathrm{T}$ cells, which may play a central role in the development of chronic colitis via the secretion of Th1 proinflammatory cytokines (13). FTY720 induced a reduction of the $\mathrm{CD}^{+} \mathrm{T}$ lymphocytes subpopulation, in

\section{DSS colitis}

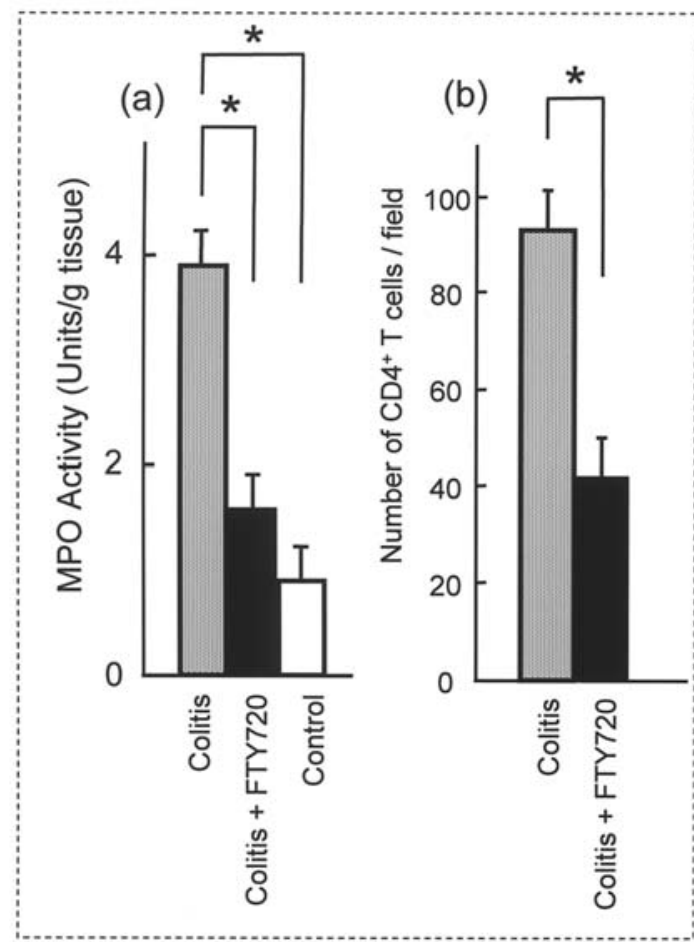

$\mathrm{CD} 4^{+} \mathrm{CD} 62 \mathrm{~L}^{+}$transfer colitis

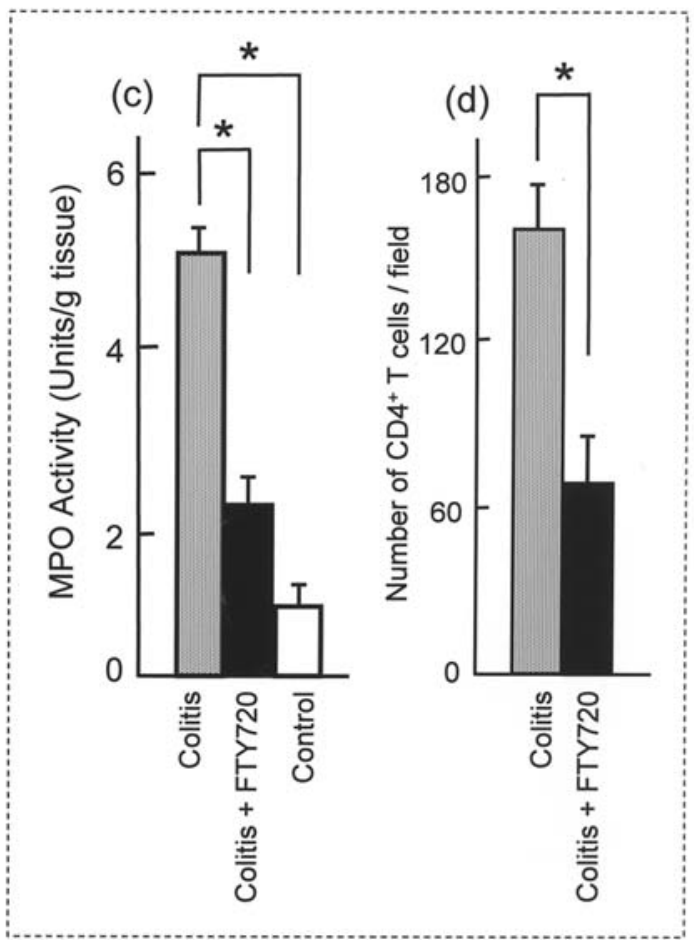

Figure 6. Tissue myeloperoxidase (MPO) activity and number of infiltrated $\mathrm{CD}^{+} \mathrm{T}$ cells in the colonic lamina propria. The tissue MPO activity was measured by the method described in Materials and methods. The number of infiltrated $\mathrm{CD}^{+} \mathrm{T}$ cells was determined by high magnitude ( $\mathrm{x} 400$ ) observation of immunostained samples. ${ }^{*} \mathrm{P}<0.05$. 
particular Th1 cells, in the colonic lamina propria, accompanied by a decrease in the severity of the colitis (13). It was suggested that FTY720 ameliorated chronic colitis in IL-10 ${ }^{-/-}$ mice through a depletion of the peripheral lymphocytes by promoting their sequestration in the secondary lymphoid tissues and the consequent reduction of the homing of lymphocytes into the lamina propria.

To further investigate the effects of FTY720 on the development of experimental colitis we used two different models, DSS-colitis and $\mathrm{CD} 4{ }^{+} \mathrm{CD} 62 \mathrm{~L}^{+} \mathrm{T}$ cell transfer colitis. DSS and the transfer of $\mathrm{CD}^{+}{ }^{+} \mathrm{CD} 62 \mathrm{~L}^{+} \mathrm{T}$ cell into SCID mice caused a substantial degree of inflammation and tissue injury in the mouse colon, which was characterized by the infiltration of inflammatory cells, epithelial disruption, edema and hemorrhage. The degree of these changes was substantially reduced in mice treated with FTY720. We have shown that the antiinflammatory effects of FTY720 involve a reduction in myeloperoxidase activity and a reduction in the number of infiltrating $\mathrm{CD}^{+}$T cells. Thus, FTY720 ameliorated the development of both DSS-colitis and CD4 ${ }^{+} \mathrm{CD} 62 \mathrm{~L}^{+} \mathrm{T}$ cell transfer colitis, and these findings in different colitis models suggest the potential application of FTY720 as a novel therapeutic agent for IBD patients.

The development of both DSS-colitis and CD4 ${ }^{+} \mathrm{CD} 62 \mathrm{~L}^{+}$ $\mathrm{T}$ cell transfer colitis have been reported to be associated with T cell activation. DSS is a sulfated polymer that is thought to induce mucosal injury and inflammation through a direct toxic effect on the epithelium, with the subsequent recruitment and activation of both macrophages and $\mathrm{T}$ cells, resulting in the induction of Th1 and Th2 cytokines and other inflammatory mediators which promote the development of colitis $(14,17,21)$. On the other hand, $\mathrm{CD} 4{ }^{+} \mathrm{CD} 62 \mathrm{~L}^{+} \mathrm{T}$ cell transfer colitis is widely used to investigate the role of specific $\mathrm{T}$ cells in the induction of intestinal inflammation, because colitis is mediated by the transfer of 'pathogenic' $\mathrm{CD} 4{ }^{+}$lymphocytes into immune deficient mice $(15,16)$. Since the infiltration of $\mathrm{CD}^{+} \mathrm{T}$ cells into the colonic lamina propria was significantly reduced by FTY720 in two colitis models, it is possible to explain that the molecular mechanisms underlying the therapeutic effects of FTY720 against DSS-colitis and $\mathrm{CD} 4{ }^{+} \mathrm{CD} 62 \mathrm{~L}^{+} \mathrm{T}$ cell transfer colitis are associated with its actions to the promote sequestration of $\mathrm{T}$ cells in secondary lymphoid tissues.

In conclusion, we have demonstrated that a novel lymphocyte homing reagent, FTY720, effectively prevented the development of DSS- and CD $4{ }^{+} \mathrm{CD} 62 \mathrm{~L}^{+} \mathrm{T}$ cell transfercolitis. The most likely mechanism responsible for these effects is an accelerated sequestration of circulating lymphocytes into secondary lymphoid tissues, resulting in a reduction of circulating lymphocytes and an inhibition of their migration to inflammatory sites. Since FTY720 exerts potent immunosuppressive effects without any down-regulation of $\mathrm{T}$ cell functions, FTY720 may be a useful for the treatment of IBD patients.

\section{References}

1. Podolsky DK: Lessons from genetic models of inflammatory bowel disease. Acta Gastroenterol Belg 60: 163-165, 1997.

2. Podolsky DK: The future of IBD treatment. J Gastroenterol 38 (Suppl. 15): S63-S66, 2003.
3. Podolsky DK: IBD: the dialectic of clinical advances and challenges. Dig Liver Dis 37: 1-2, 2005.

4. Hibi T and Ogata H: Novel pathophysiological concepts of inflammatory bowel disease. J Gastroenterol 41: 10-16, 2006.

5. Yopp AC, Fu S, Honig SM, Randolph GJ, Ding Y, Krieger NR and Bromberg JS: FTY720-enhanced T cell homing is dependent on CCR2, CCR5, CCR7 and CXCR4: evidence for distinct chemokine compartments. J Immunol 173: 855-865, 2004.

6. Bandhuvula P, Tam YY, Oskouian B and Saba JD: The immune modulator FTY720 inhibits sphingosine-1-phosphate lyase activity. J Biol Chem 280: 33697-33700, 2005.

7. Kharel Y, Lee S, Snyder AH, Sheasley-O'neill S L, Morris MA, Setiady Y, Zhu R, Zigler MA, Burcin TL, Ley K, Tung KS, Engelhard VH, Macdonald TL, Pearson-White S and Lynch KR: Sphingosine kinase 2 is required for modulation of lymphocyte traffic by FTY720. J Biol Chem 280: 36865-36872, 2005.

8. Muller H, Hofer S, Kaneider N, Neuwirt H, Mosheimer B, Mayer G, Konwalinka G, Heufler C and Tiefenthaler M: The immunomodulator FTY720 interferes with effector functions of human monocyte-derived dendritic cells. Eur J Immunol 35: 533-545, 2005.

9. Pabst O, Herbrand H, Willenzon S, Worbs T, Schippers A, Muller W, Bernhardt G and Forster R: Enhanced FTY720mediated lymphocyte homing requires $G\{$ alpha $\}$ i signaling and depends on beta2 and beta7 integrin. J Immunol 176: 1474-1480, 2006

10. Sawicka E, Dubois G, Jarai G, Edwards M, Thomas M, Nicholls A, Albert R, Newson C, Brinkmann V and Walker C: The sphingosine 1-phosphate receptor agonist FTY720 differentially affects the sequestration of $\mathrm{CD} 4^{+} / \mathrm{CD} 25^{+} \mathrm{T}$-regulatory cells and enhances their functional activity. J Immunol 175: 7973-7980, 2005

11. Sawicka E, Zuany-Amorim C, Manlius C, Trifilieff A, Brinkmann V, Kemeny DM and Walker C: Inhibition of Th1and Th2-mediated airway inflammation by the sphingosine 1phosphate receptor agonist FTY720. J Immunol 171: 6206-6214, 2003.

12. Pabst O, Herbrand H, Willenzon S, Worbs T, Schippers A, Muller W, Bernhardt G and Forster R: Enhanced FTY720mediated lymphocyte homing requires Galphai signaling and depends on beta2 and beta7 integrin. J Immunol 176: 1474-1480, 2006.

13. Mizushima T, Ito T, Kishi D, Kai Y, Tamagawa H, Nezu R, Kiyono $\mathrm{H}$ and Matsuda $\mathrm{H}$ : Therapeutic effects of a new lymphocyte homing reagent FTY720 in interleukin-10 gene-deficient mice with colitis. Inflamm Bowel Dis 10: 182-192, 2004.

14. Egger B, Bajaj-Elliott M, MacDonald TT, Inglin R, Eysselein VE and Buchler MW: Characterisation of acute murine dextran sodium sulphate colitis: cytokine profile and dose dependency. Digestion 62: 240-248, 2000

15. Neurath MF, Weigmann B, Finotto S, Glickman J, Nieuwenhuis E, Iijima H, Mizoguchi A, Mizoguchi E, Mudter J, Galle PR, Bhan A, Autschbach F, Sullivan BM, Szabo SJ, Glimcher LH and Blumberg RS: The transcription factor T-bet regulates mucosal $\mathrm{T}$ cell activation in experimental colitis and Crohn's disease. J Exp Med 195: 1129-1143, 2002.

16. Obermeier F, Strauch UG, Dunger N, Grunwald N, Rath HC, Herfarth H, Scholmerich J and Falk W: In vivo CpG DNA/tolllike receptor 9 interaction induces regulatory properties in $\mathrm{CD} 4{ }^{+} \mathrm{CD} 62 \mathrm{~L}^{+} \mathrm{T}$ cells which prevent intestinal inflammation in the SCID transfer model of colitis. Gut 54: 1428-1436, 2005.

17. Cooper HS, Murthy SN, Shah RS and Sedergran DJ: Clinicopathologic study of dextran sulfate sodium experimental murine colitis. Lab Invest 69: 238-249, 1993.

18. Brinkmann V and Lynch KR: FTY720: targeting G-proteincoupled receptors for sphingosine 1-phosphate in transplantation and autoimmunity. Curr Opin Immunol 14: 569-575, 2002.

19. Brinkmann V: FTY720: mechanism of action and potential benefit in organ transplantation. Yonsei Med J 45: 991-997, 2004

20. Tedesco-Silva H, Mourad G, Kahan BD, Boira JG, Weimar W, Mulgaonkar S, Nashan B, Madsen S, Charpentier B, Pellet P and Vanrenterghem Y: FTY720, a novel immunomodulator: efficacy and safety results from the first phase 2A study in de novo renal transplantation. Transplantation 79: 1553-1560, 2005.

21. Sivakumar PV, Westrich GM, Kanaly S, Garka K, Born TL, Derry JM and Viney JL: Interleukin 18 is a primary mediator of the inflammation associated with dextran sulphate sodium induced colitis: blocking interleukin 18 attenuates intestinal damage. Gut 50: 812-820, 2002. 